\title{
THE FIRST PAPER ABOUT EXCITING OF FLUORESCENCE OF LIQUID BIPHENYL AND PHENANTHREN BY FAST ELECTRONS BY LIESELOTT HERFORTH AND HARTMUT KALLMANN
}

\author{
S Niese \\ Niese Umweltberatung Mohorn, Am Silberblick 9, 01723 Wilsdruff, Germany. Email: S.Niese@fz-rossendorf.de.
}

ABSTRACT. The first measurements of the fluorescence of liquid organic compounds after excitation with nuclear radiation were published 1948 in a thesis of L Herforth and a paper by Herforth and Kallmann (1949).

With the title "Die Fluoreszenzanregung von festen und flüssigem Naphthalin, Diphenyl und Phenanthren durch Alphateilchen, schnelle Elektronen und Gammastrahlen" a paper was published by Lieselott Herforth and Hartmut Kallmann in the Annalen der Physik (Herforth and Kallmann 1949). It was received by the editor on 10 August 1948 and contains results of a thesis (Herforth 1948) "Die Fluoreszensanregung organischer Substanzen mit Alphateilchen, schnellen Elektronen und Gammastrahlen". In the paper and in her thesis, L Herforth has presented results of the measurement of the fluorescent yield of molten biphenyl and phenanthrene. She found that the yield of molten biphenyl and phenanthrene was one order of magnitude lower than in the solid state.

Herforth explained the reduction of the fluorescent yield by quenching and stated that the quenching should be high in the case of a low symmetry of the geometric package of the molecules and strong fluctuations of the distances between the molecules. From this she explained the reduced fluorescent yield by melting of the substances. The lower quenching in solid materials demonstrates that the molecules in this state only seldom come close together by thermal oscillation to be able to convert the electronic energy of the molecules to kinetic energy. The stronger quenching of identical than foreign molecules e.g. in solutions is explained by a special resonant interaction between identical molecules, which causes a strong approximation and attraction of the molecules and the approximation of the corresponding potential curves. She found that after excitation by electrons the fluorescence light have a similar spectrum as by excitation by ultraviolet light. From this she conclude, that the fluorescent light excitation and quenching mechanism is similar after excitation by ultraviolet light and fast electrons.

The measurement of liquid organic compounds were part of a systematic investigation of the properties of organic scintillators. Beginning with 1947 some papers have been published about the development of a new type of counter with scintillating inorganic and organic compounds like $\mathrm{ZnS}$, CdS (Broser and Kallmann 1947a, 1947b, 1948) and aromates. Special attention have been paid to the scintillating properties of solid aromatic compounds (Broser and Kallmann 1947b; Broser et al. 1948; Herforth and Kallmann 1949; Herforth 1950). The first results became public after a lesson of H Kallmann at the Dahlem-Colloquium 5 June 1947. From this a report was given in a popular journal (Bloch 1947). Some days later, M Deutsch from the Massachusetts Institute of Technology (MIT) obtained an extended report about this lesson. And he confirmed the published results about the scintillating properties of naphthalene in an internal report (Deutsch 1947) and his results have been referred in a scientific journal (Bell 1948). The discovery of the scintillation of organic compounds are described in two papers (Niese 1999, 2001).

At the end of 1948, H Kallmann went to the USA, where he continued the research in scintillation of organic liquids (Kallmann and Furst 1950) and the contract of L Herforth with the Kaiser-Wilhelm -Institute for physical chemistry in Berlin-Dahlem was finished and the partition of Germany and 
Berlin occurred. Nevertheless, she performed some further experiments (Herforth 1950) there. Then she continued her carrier in an institute of medicine and biology in Berlin-Buch where she applied the fluorescence of organic compounds for the detection of carcinogenic substances. The investigations of organic scintillators have not been continued in Berlin. The most important further contributions in development and application of organic scintillators were done in the USA. Processes of energy transfer from molecules excited by radiation to fluorescence light at first discussed by Herforth and Kallmann were investigated in more detail (Kallmann and Furst 1950). The photon yield of liquid scintillator were enhanced and reached using a solution of $5 \mathrm{~g} / \mathrm{L}$ terphenyl in xylene the value of a single crystal of anthracene (Raben and Bloemberger 1951). They had tested a large number of scintillating substances for liquid scintillation counting (LSC), too. Hayes and collaborators from the Los Alamos Scientific Laboratory (cit. Peng 1992) studied the relation of chemical structure and scintillating properties of aryl substituted heterocyclic compounds and found the highest photon yield with a ternary mixture of 2,5-diphenyl oxazole (POP) as scintillator and 1,4-bis-2-(5-phenyloxazolyl)-benzene (POPOP) as wave length shifter in toluene (Hayes and Gould 1953). Over many decades this mixture was the mostly used liquid scintillator.

The discrimination of electronic noises of the PMT by the use of two coincident PMT (Reynolds et al. 1950) enabled the measurement of ${ }^{3} \mathrm{H}$ and other nuclides which emit only low energy beta-particles and Hayes and RC Gould (1953) have given ${ }^{3} \mathrm{H}$-labeled compounds directly into the liquid scintillator. This procedure has not found any fundamental changes up to now. A number of interesting details about the history of LSC are given in a historical paper (Peng 1992).

\section{REFERENCES}

Bell PR. 1948, The use of anthracene as a scintillation counter. Physics Review 73:1405-6.

Broser I. 1947. Über die Anregung von Leuchtstoffen durch Alphateilchen. Thesis. TU Berlin-Charlottenburg. Presented 5 April 1947.

Broser I, Kallmann H. 1947a. Über den Elementarprozeß der Lichtanregung in Leuchtstoffen durch $\alpha$-Teilchen, schnelle Elektronen und $\gamma$-Quanten I. Z. Naturforschung 2a:439-43.

Broser I, Kallmann H. 1947b. Über den Elementarprozeß der Lichtanregung in Leuchtstoffen durch $\alpha$-Teilchen, schnelle Elektronen und $\gamma$-Quanten II. Z. Naturforschung 2a:642-50.

Broser I, Kallmann H. 1948. Die Bestimmung der Energie von Alphateilchen mit dem Kristall-Leuchtmassenzähler. Annalen der Physik 6.3:317-21.

Broser I, Herforth L, Kallmann H, Martius U. 1948. Über den Elementarprozeß der Lichtanregung von Leuchtstoffen III: Die Anregung des Naphthalins (Weitere Versuche mit dem Leuchtmassenzähler). Z. Naturforschung 3a:6-15.

Deutsch M. 1947. Naphthaline as scintillator. Massachusetts Institute of Technology, Institute of Nuclear Sciences. MIT-INS Report No. 3. Cited by Bell 1948.

Herforth L, Kallmann H. 1949. Die Fluoreszensanregung von festem und flüssigem Naphthalin, Diphenyl und Phenanthren durch Alphateilchen, schnelle Elektronen und Gammastrahlung. Annalen der Physik 6.4: 231-45.

Herforth L. 1948. Die Fluoreszensanregung organischer
Substanzen mit Alphateilchen, schnellen Elektronen und Gammastrahlen. Thesis. Berlin-Charlottenburg. Presented 13 September 1948.

Herforth L. 1950. Die Fluoreszensanregung organischer Substanzen durch Alphateilchen und Gammastrahlen. Annalen der Physik 6.7:312-20.

Hayes FN, Gould RC. 1953. Liquid scintillation counting of H-3 labelled water and organic compounds. Science 117:480.

Kallmann H. 1947. Lesson in a colloquium in BerlinDahlem, reported by Bloch, W. "Kann man Elektronen sehen". Natur und Technik 13:15.

Kallmann H, Furst M. 1950. Physics Review 79:857.

Kallman H, Furst M. 1958. The basic processes occuring in the liquid scintillators. In: Bell CG Jr, Hayes FN, editors. Liquid scintillation counting. Pergamon Press.

Niese S. 1999. The discovery of organic solid and liquid scintillators by $\mathrm{H}$ Kallmann and L Herforth 50 years ago. Journal of Radioanalytical and Nuclear Chemistry 241:499-501.

Niese S. 2001. Scintillation of solid and liquid organic compounds discovered by H Kallmann, L Herforth, I Broser. Journal of Radioanalytical and Nuclear Chemistry. In press.

Peng C-T. 1993. The history of liquid scintillation counting. In: Noakes JE, Schönhofer F, Polach A, editors. LSC 92. Tucson, Arizona: Radiocarbon. p 1-13.

Raben MS, Bloemberger N. 1951. Science 114:363.

Reynolds GT, Harrison FB, Salvini G. 1950. Liquid scintillation counter. Physics Review 78:488. 